\title{
Virus and Virus-like Particles Affecting Cephalopods
}

\author{
María Prado-Álvarez and Pablo García-Fernández
}

\begin{abstract}
This chapter compiles the information available to date regarding virus affecting different species of cephalopods. A clear evidence of a virus-related disease on cephalopods was not stablished yet. However, the first description of a virus-like in Octopus vulgaris was observed in nodular tumors that finally caused the death of the animal. It is noteworthy that not too much effort has been focused on this area to date. However, the incidence of viruses in cephalopods might be further investigated since the attention on these species as an alternative to the aquaculture sector is increasing rapidly over last years and huge efforts are being made to stablish new cultures.
\end{abstract}

\section{Keywords}

Cephalopod diseases $・$ Virus $・$ Octopus $・$ Cuttlefish $・$ Nautilus $・$ Squid

\subsection{Introduction}

Virus-like descriptions on cephalopods are rather scarce and quite spread over time. However, the incidence of viral diseases on bivalve and gastropod mollusks has been extensively studied (Arzul et al. 2017). Since first descriptions in 1971 in Octopus vulgaris and Sepia officinalis, only three more observations were reported in cephalopods in more species of the genus Octopus and Nautilus and in the squid Loligo pealei (Table 7.1).

Family classification was initially made based on similarities to viral mammalian diseases caused by virus (Farley 1978). In more recent studies, molecular diagnosis was applied to amplify genomic material and search for homology in public databases. However, it is important to remark that classification made on this chapter is based only on the information available to date which in most cases were made based on

M. Prado-Álvarez $(\bowtie) \cdot$ P. García-Fernández Aquatic Molecular Pathobiology Group, Institute of Marine Research, Spanish National Research Council (CSIC), 36208 Vigo, Pontevedra, Spain

e-mail: mprado@iim.csic.es

P. García-Fernández

e-mail: pablo.garcia@iim.csic.es morphology observed under transmission electron microphotographs. Further analysis would be necessary to deepen on the effect caused by virus on these animals, especially considering the increasing interest on these animals as an alternative product to satisfy the global demand on the aquaculture sector. However, advances in this scope become a big challenge to the scientific community in part due to the difficulty to obtain specific cell lines and culture systems.

\subsection{Iridoviridae}

First observation of virus-like particles affecting a cephalopod was made in 1971 in O. vulgaris (Rungger et al. 1971). Nodular tumors on tentacles of $1 \mathrm{~mm}$ diameter were observed at early stages. However, these tumors can develop and grow up to 5-10 $\mathrm{mm}$ and be extended to the ventral surface and also the siphon. The progress of the infection leads to self-mutilation of affected areas, and death occurred after 3-5 months in captivity. Electron micrographs of tumor tissues at early stage showed organized virus-like particles that appeared in groups of 300 particles with hexagonal and electrodense internal cores and $120 \mathrm{~nm}$ diameter. It was also observed an envelope surrounding these particles in disaggregated tissues. Mortality was 
Table 7.1 Summary of descriptions of viruses and virus-like particles in cephalopods

\begin{tabular}{|l|l|l|l|}
\hline Year & Cephalopod sp. & Virus family & Reference \\
\hline 1971 & Octopus vulgaris & Iridoviridae & Rungger et al. (1971) \\
\hline 1971 & Sepia officinalis & Reoviridae & Devauchelle and Vago (1971) \\
\hline 1988 & Loligo pealei & - & Pers. Comm. to authors (Hanlon and Forsythe 1990) \\
\hline 1988 & Octopus spp. & - & Pers. Comm. to authors (Hanlon and Forsythe 1990) \\
2006 & Nautilus spp. & Iridoviridae & Gregory et al. (2006) \\
\hline 2015 & O. vulgaris & Nodaviridae & Fichi et al. (2015) \\
\hline 2018 & O. vulgaris & Malacoherpesviridae & Prado-Álvarez et al. (in preparation) \\
\hline
\end{tabular}

described to be due to starvation, self-mutilation, or the presumed viral infection associated with these tumors. In 1978, Farley classified this virus particle as Iridoviridae (Farley 1978). The family Iridoviridae comprises icosahedral double-stranded DNA viruses and mainly affects ectothermic vertebrates, insects, and crustaceans (Chinchar et al. 2017).

Morphology similar to an Iridovirus was found in renal tubular epithelial cells of Nautilus spp. (Gregory et al. 2006). Viral particles were enveloped and measured $176 \mathrm{~nm}$ in diameter. Moreover, this was the first characterization that included molecular identification and sequencing to confirm the similarity to an amphibian Iridovirus.

\subsection{Reoviridae}

Devauchelle and Vago (1971) reported a no-pathogenic incidence of a virus in the European cuttlefish, Sepia officinalis. These non-enveloped particles were observed on epithelial cells on the stomach and were $75 \mathrm{~nm}$ in diameter. Initial studies suggested that these particles could correspond to the family Reoviridae. Reoviridae are viruses with icosahedral symmetry and double-stranded RNA. However, they could be spherical and infect a wide number of hosts including vertebrates, invertebrates, plants, protists, and fungi (Lefkowitz et al. 2018).

\subsection{Nodaviridae}

Finally, a betanodavirus (family Nodaviridae) was described affecting $O$. vulgaris (Fichi et al. 2015) particularly in white lesions observed in the skin, and also in eye and branchial heart tissues. Molecular detection by PCR and quantitative PCR confirmed the incidence of betanodavirus. However, one animal showing similar symptom seemed to be affected by a nodavirus-like particle. Virions belonging to this family are non-enveloped, $30 \mathrm{~nm}$ in diameter, and single-stranded RNA (Artimo et al. 2012).

\subsection{Unclassified Viruses}

Hanlon and Forsythe revised in 1990 the descriptions of virus-like particles in cephalopods made to date (Hanlon and Forsythe 1990). Apart from the two descriptions detailed
Fig. 7.1 In situ hybridization labeling of ostreid herpesvirus. Positive cells are labeled in blue. Gill tissue of adult $O$. vulgaris (a). Detailed area at higher magnification (b). Scale bar $=10 \mu \mathrm{m}$
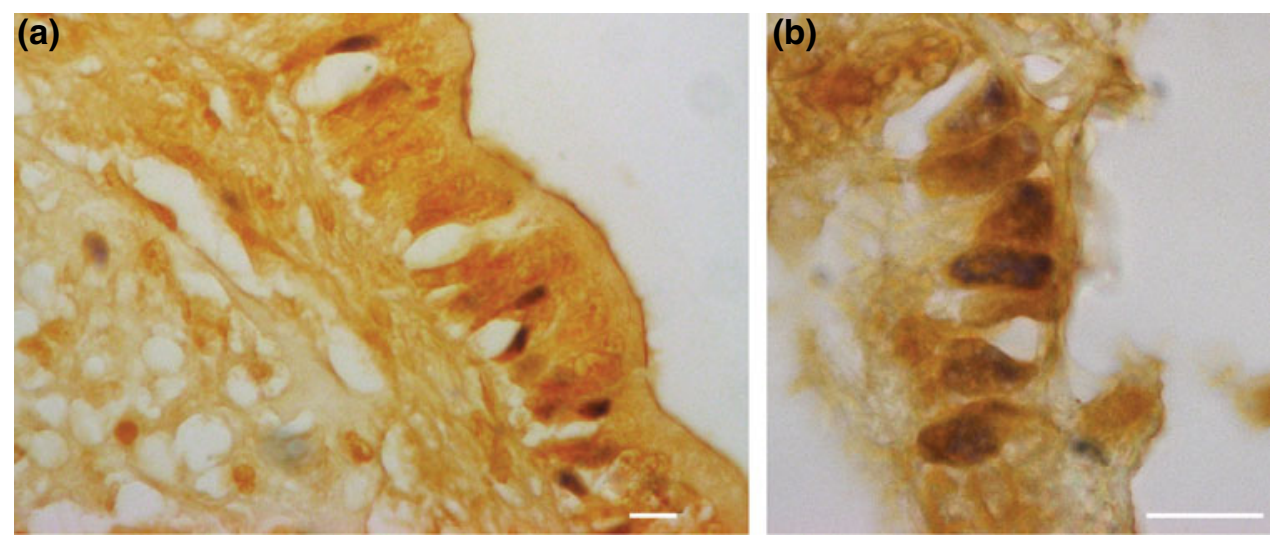
above, two more annotations were made based on personal communications to the authors. One was in the squid Loligo pealei on which cytoplasmic inclusions were found in the digestive gland and the other on different species of octopus in New Zealand and the east and west coasts of USA.

More recently, an interspecific study of the incidence of the ostreid herpesvirus demonstrated that the virus was widely spread in oyster-culturing areas. This virus belongs to the family Malacoherpesviridae and caused massive mortalities in spat and juvenile oysters (Prado-Álvarez et al. 2016). This family comprised of enveloped double-stranded DNA viruses, 150-200 nm in diameter, and affects to mollusks (Davison et al. 2009). A collection of samples of $O$. vulgaris including paralarvae at different stages and adult animals were analyzed by molecular techniques. Homology searches on positive results showed the highest similarity to the ostreid herpesvirus- $1 \mu$ Var (unpublished data). Moreover, ostreid herpesvirus-specific probes for in situ hybridization were positively labeled on epithelial cells of the gills (Fig. 7.1). Further analysis should be carried out to decipher if this virus could be the causative agent of any pathology in these animals.

\subsection{Concluding Remarks}

Several virus and virus-like particles were described on cephalopods. However, a clear incidence associated with a virus-related disease was not well described to date. It deserves to be further investigated as cephalopods could be considered as an alternative to be aquacultured and satisfy the global demand.

\section{References}

Artimo P, Jonnalagedda M, Arnold K et al (2012) ExPASy: SIB bioinformatics resource portal. Nucleic Acids Res 40:W597-W603

Arzul I, Corbeil S, Morga B, Renault T (2017) Viruses infecting marine molluscs. J Invertebr Pathol 147:118-135

Chinchar VG, Hick P, Ince IA et al (2017) ICTV report consortium. ICTV virus taxonomy profile: Iridoviridae. J Gen Virol 98:890-891

Davison AJ, Eberle R, Ehlers B et al (2009) The order Herpesvirales. Arch Virol 154:171-177

Devauchelle G, Vago C (1971) Particles of viral asepct in stomach cells of the cuttle-fish Sepia officinalis L. (Mollusca, Cephalopoda). C R Acad Sci Hebd Seances Acad Sci D 272(6):894-6

Farley C (1978) Viruses and viruslike lesions in marine mollusks. Mar Fish Rev 40:18-20

Fichi G, Cardeti G, Perrucci S et al (2015) Skin lesion-associated pathogens from Octopus vulgaris: first detection of Photobacterium swingsii, Lactococcus garvieae and betanodavirus. Dis Aquat Organ 115:147-156

Gregory CR, Latimer KS, Pennick K, Benson K, Moore T (2006) Novel Iridovirus in a Nautilus (Nautilus Spp.). J Vet Diagnostic Investig 18:208-211

Hanlon RT, Forsythe JW (1990) Diseases of Mollusca: Cephalopoda. Diseases caused by microorganisms. In: Kinne O (ed) Diseases of marine animals, vol III. Biologische Anstalt Helgoland, Hamburg, Germany, pp 23-46

Lefkowitz EJ, Dempsey DM, Hendrickson RC, Orton RJ, Siddell SG, Smith DB (2018) Virus taxonomy: The database of the International Committee on Taxonomy of Viruses (ICTV). Nucleic Acids Res 46: D708-D717

Prado-Álvarez M, Darmody G, Hutton S, O'Reilly A, Lynch SA, Culloty SC (2016) Occurrence of OsHV-1 in Crassostrea gigas Cultured in Ireland during an exceptionally warm summer. Selection of less susceptible oysters. Front Physiol 7:492

Rungger D, Rastellt M, Braendle E, Malsberger RG (1971) A viruslike particle sssociated with lesions in the muscles of Octopus vulgaris. J Invertebr Pathol 17:72-89

\footnotetext{
Open Access This chapter is licensed under the terms of the Creative Commons Attribution 4.0 International License (http://creative commons.org/licenses/by/4.0/), which permits use, sharing, adaptation, distribution and reproduction in any medium or format, as long as you give appropriate credit to the original author(s) and the source, provide a link to the Creative Commons licence and indicate if changes were made.
}

The images or other third party material in this chapter are included in the chapter's Creative Commons licence, unless indicated otherwise in a credit line to the material. If material is not included in the chapter's Creative Commons licence and your intended use is not permitted by statutory regulation or exceeds the permitted use, you will need to obtain permission directly from the copyright holder. 